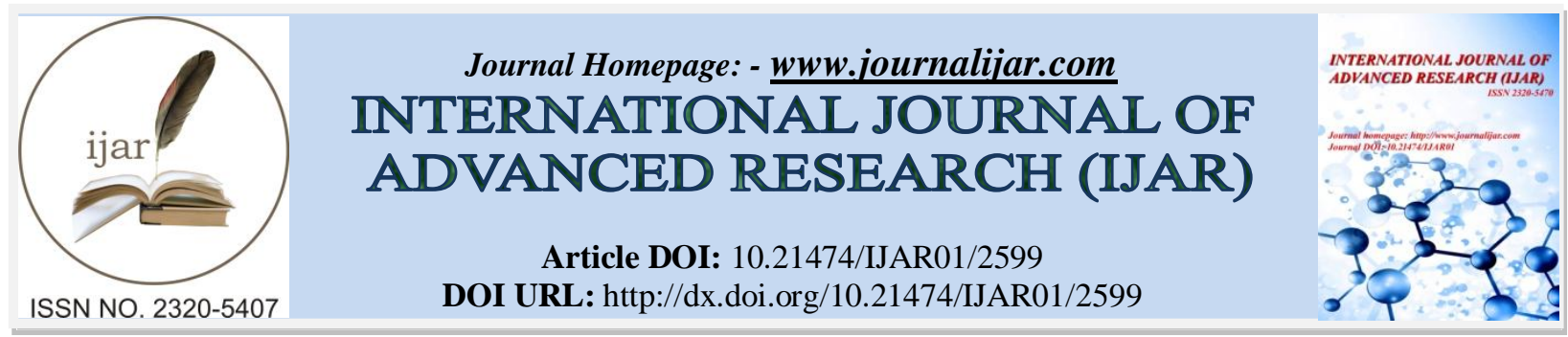

RESEARCH ARTICLE

\title{
WINDOW AIR-CONDITIONER USING LPG.
}

\author{
Dr. Ajoy Kumar \\ Principal, Chhatrapati Shivaji Maharaj Institute of Technology Panvel, University of Mumbai ,India.
}

\section{Manuscript Info}

Manuscript History

Received: 28 October 2016

Final Accepted: 27 November 2016

Published: December 2016

Key words:-

C.O.P., Refrigerating effect, Absorbent, Aqua-ammonia.

\section{Abstract}

A few days ago refrigeration was regarded as luxurious branch of engineering in the whole world but it has become a part and parcel of present society. Absorption refrigeration cycle is one of the oldest known cycles used for producing refrigeration effect. Great strides had been made to use the heat energy instead of work energy for producing refrigeration as it can be available from the waste fuel and solar energy. The one disadvantage of the system is its low coefficient of performance (C.O.P.) as compared to the vapor compression system, but it can be acceptable if we use heat energy which is going waste or solar energy; as it is available at no cost.

This paper deals with the system which is designed and fabricated, using fuel of Liquefied Petroleum Gas (LPG) as a heating media to generator of vapor absorption system. It not only uses fuel of high calorific value and low cost but also to increase the C.O.P. of system on increased load of the room by regulating the flame temperature and pressure inside the generator such that the system can be affected. Capacity of system is 1.5 T.R.

Copy Right, IJAR, 2016,. All rights reserved.

\section{Introduction:-}

As we know that there are two types of refrigeration system namely vapor absorption and vapor compression. The vapor absorption refrigeration is a heat operated system and is older than vapor compression system. The vapor absorption system comprises either two fluid systems $\left(\mathrm{NH}_{3}+\mathrm{H}_{2} \mathrm{O}, \mathrm{Li}-\mathrm{Br}+\mathrm{H}_{2} \mathrm{O}\right)$ or three fluid systems. It consists mainly of the evaporator, absorber, solution pump, generator and condenser. Absorption system is usually designed to use steam either at high pressure or at low pressure. Waste or exhaust steam from other equipment may be used. There is no need for any electric power, although the pump is usually motor driven. At reduced loads the absorption unit is almost as different as at full capacity. Load variation is met by controlling quantity of aqua circulated and quantity of heat supplied to the generator. Space requirement and automatic control requirements favor the absorption system more and as desired temperature drops.

As far as properties of ideal refrigerant-absorbent combination are concerned, it should have high solubility at conditions in the absorbent absorber but should have low solubility at conditions in the generator. The solution should have low specific heat and low viscosity. It should be non-corrosive in nature Hoinworth listed 49 refrigerants coupled with various absorbents to give 180 combinations as possibilities. Of the many combinations that have been tried, only the ammonia-water and lithium-bromide water cycles remained in common use in airconditioning applications. In addition, ammonia-water absorption system finds an important place in large tonnage industrial applications. Hattem and Dato (1983) [1] described an active solar cooling system, using a $\mathrm{LiBr}-\mathrm{H} 2 \mathrm{O}$ 
absorption machine. Many researchers [2-7] have experimentally studied the heat transfer Coefficients in two-phase flow for the water/lithium bromide mixture used in solar absorption refrigeration systems. Khaled AlQdah (2011) [8] conducted an experimental study to evaluate the performance of aqua ammonia in air conditioner system using exhaust waste energy as an external heating source to the generator.

The objective of this paper is to design, fabricate and charge two fluid vapor absorption for window air conditioner using ammonia and water.

\section{Property of Ammonia-water combination}

1. $1 \mathrm{~m}^{2}$ of water absorbs $800 \mathrm{~m}^{3}$ of $\mathrm{NH}_{3}$

2. Latent heat of $\mathrm{NH}_{3}=1312.6 \mathrm{KJ} / \mathrm{Kg} \mathrm{K}$ at $-15^{\circ} \mathrm{C}$

3. Critical temperature of $\mathrm{NH}_{3}=132^{\circ} \mathrm{C}$

4. Specific heat of $\mathrm{NH}_{3}=4.638 \mathrm{KJ} / \mathrm{Kg} \mathrm{K}$ at $0^{0} \mathrm{C}$

5. Boiling point at atmospheric pressure $=-33^{0} \mathrm{C}$

\section{Experimental set-up:-}

Fig. 1 shows the complete set-up of the fabricated arrangement for ammonia-water vapor absorption system used during experimentation. According to the calculation, total capacity of the system has been achieved as $1.5 \mathrm{TR}$ with following assumptions:

1. Temperature difference required for heat transfer in absorber and condenser $=3^{0} \mathrm{C}$.

2. Degassing range which is the difference between the concentration of strong solution and week solution is 0.23 $\mathrm{kg} / \mathrm{kg}$ of aqua by weight.

3. Concentration of vapor leaving the analyzer $=0.99$.

4. Concentration of ammonia vapor required in the condenser is 0.995 .

5. Change in kinetic and potential energy is negligible.

The ammonia in water solution is contained in the liquid reservoir and is replenished continually by fresh solution drawn from the absorber. The strength of this solution is about $38 \%$ ammonia by weight. The solution leaves the reservoir at the bottom and throws the liquid heat exchanger into the top of the analyzer. In the liquid heat exchanger, it receives heat and some ammonia gas is generated. These bubbles up through the liquid and leaves analyzer enroot to the rectifier. Intense heat supplied to the generator, derives out the bulk of ammonia vapors. The conditions in this tube are unsteady and surges of vapor caring liquid into the separating vessel.

The liquid collected in the separating vessel passes through the liquid heat exchanger where it gives up heat to the in going rich solution, before entering top of absorber. The vapor collected in the separating vessel tube, though mainly ammonia is seriously contaminated with water vapor. The mixed vapor is once again passed through analyzer where it loses most of its water vapor. The nearly pure ammonia then passes through the rectifier and condenser as usual.

The ammonia now flows through the evaporator and hence the coldest part of the evaporator is at the top. This part forms the air conditioning with blower and diffuser arranged on shaft of motor while the part with blower cools the rest of refrigerated correction.

Before charging the system with aqua-ammonia, it has been allowed to go through hydraulic test, compressed air test and vacuum test for preventing leakage out of it.

\section{Calculation for the Result:-}

Design and experimentation has been done under the summer condition with relative humidity of $55 \%$ and DBT $=22^{\circ} \mathrm{C}$ for inside and $\mathrm{WBT}=26^{\circ} \mathrm{C} \& \mathrm{DBT}=37.5^{\circ} \mathrm{C}$ for outside.

Making the use of enthalpy concentration diagram as shown in Fig.2, the corresponding pressures are:

1. $\mathrm{P}_{1}=16$ bar $=$ Condenser pressure

2. $\mathrm{P}_{4}=4 \mathrm{bar}=$ Evaporator pressure

3. $\mathrm{T}_{\mathrm{c} \text { in }}=40^{\circ} \mathrm{C}$ at point 5

4. $\mathrm{Tc}_{\text {out }}=90^{\circ} \mathrm{C}$ at point 6

5. Temperature of hot fluid at inlet of heat exchanger $=140{ }^{\circ} \mathrm{C}$

6. Temperature of cold fluid at outlet of 
heat exchanger $=85^{\circ} \mathrm{C}$

After plotting the chart, we have:

$\mathrm{h}_{1}=1660 \mathrm{KJ} / \mathrm{kg}$

$\mathrm{h}_{2}=\mathrm{h}_{3}=580 \mathrm{KJ} / \mathrm{kg}$

$\mathrm{h}_{4}=1640 \mathrm{KJ} / \mathrm{kg}$

$\mathrm{h}_{5}=\mathrm{h}_{6}=75 \mathrm{KJ} / \mathrm{kg}$

$\mathrm{h}_{7}=310 \mathrm{KJ} / \mathrm{kg}$

ha $=500 \mathrm{KJ} / \mathrm{kg}$

$\mathrm{h}_{8}=580 \mathrm{KJ} / \mathrm{kg}$

$\mathrm{h}_{9}=\mathrm{h}_{10}=300 \mathrm{KJ} / \mathrm{kg}$

$\mathrm{Cs}=\mathrm{C}_{7}($ Strong solution $)=0.41$

And $\mathrm{C}_{\mathrm{w}}=\mathrm{C}_{8}$ (Weak solution $)=0.18$

$\mathrm{h}_{12}=1940 \mathrm{KJ} / \mathrm{kg} \mathrm{C}_{11}=0.9=\mathrm{Cd}$

1. $\mathrm{m}_{\mathrm{r}}$ (Mass of flow of $\mathrm{NH}_{3}$ through evaporator)

$=(1.5 \times 3.5) /(1640-580)=0.0042 \mathrm{~kg} / \mathrm{sec}$

$=0.005 \mathrm{~kg} / \mathrm{sec}$

2. Heat supplied to $\mathrm{NH}_{3}$ in the generator

$=\mathrm{h}_{12}-\mathrm{h}_{\mathrm{a}}$

$=1940-(-500)=2440 \mathrm{KJ} / \mathrm{kg}$ of $\mathrm{NH}_{3}$

$\mathrm{Q}_{\mathrm{g}}=0.0042 \times 2440=10.24 \mathrm{~kJ} / \mathrm{sec}$

3. Heat rejected in the absorber/sec

$\mathrm{Q}_{\mathrm{a}}=\mathrm{m}_{\mathrm{r}}\left(\mathrm{h}_{4}-\mathrm{h}_{\mathrm{a}}\right)=0.0042(1640+500)$

$=8.98 \mathrm{KJ} / \mathrm{sec}$ aqua

4. Degassing $=\mathrm{C}_{\mathrm{s}}-\mathrm{C}_{\mathrm{w}}=0.41-0.188=0.23 \mathrm{~kg} / \mathrm{kg}$ of aqua

5. Heat rejected in deflamater (cooler after generator)

$=\mathrm{m}_{\mathrm{r}}\left(\mathrm{h}_{12}-\mathrm{h}_{1}\right)=0.0042(1940-1660)$

$=1.17 \mathrm{KJ} / \mathrm{sec}$

6. Heat rejected in condenser

$\mathrm{Q}_{\mathrm{c}}=\mathrm{m}_{\mathrm{r}}\left(\mathrm{h}_{1}-\mathrm{h}_{2}\right)=0.0042=(1660-580)$

$=4.53 \mathrm{~kJ} / \mathrm{sec}$

7. Heat rejected by evaporator

$=\mathrm{n}_{\mathrm{i}} \cdot \mathrm{x}\left(\mathrm{h}_{4}-\mathrm{h}_{3}\right)$

$\mathrm{Q}_{\mathrm{e}}=3.35 \times(1645-580) \mathrm{kg} / \mathrm{sec} \times \mathrm{kJ} / \mathrm{kg}$

$=3551 \mathrm{~kJ} / \mathrm{sec}$

$=3.55$ watt

System Calculation

1. Refrigeration effect $\left(\mathrm{Q}_{\mathrm{r}}\right)=\left(\mathrm{h}_{4}-\mathrm{h}_{3}\right)$

$=(16440-580)$

$=1060 \mathrm{~kJ} / \mathrm{kg}$

2. Heat rejected in condenser $\left(\mathrm{Q}_{\mathrm{c}}\right)=\mathrm{h}_{1}-\mathrm{h}_{2}$

$=(1660-580)$

$=1080 \mathrm{KJ} / \mathrm{kg}$

3. Heat removed from the absorber $\left(\mathrm{Q}_{\mathrm{a}}\right)=\mathrm{h}_{4}-\mathrm{h}_{5}$

$=(1640-75)$

$=1565 \mathrm{KJ} / \mathrm{kg}$ 


\section{Absorption System:-}

Heat to be supplied in the generator $\left(\mathrm{Q}_{\mathrm{g}}\right)=\mathrm{h}_{1}-\mathrm{h}_{7}$

$$
\begin{aligned}
& =1660-310 \\
& =1350 \mathrm{KJ} / \mathrm{kg}
\end{aligned}
$$

Theoretical C.O.P of the system $=\mathrm{Q}_{\mathrm{r}} / \mathrm{Q}_{\mathrm{g}}=1060 / 1350=0.78$

Temperature of Generator required

$$
=140^{\circ} \mathrm{C}
$$

\section{Actual C.O.P of system:-}

Heat lost by weak solution $=$ Heat gained by strong solution

$\mathrm{m}_{\mathrm{w}}\left(\mathrm{h}_{8}-\mathrm{h}_{9}\right)=\mathrm{m}_{\mathrm{s}}\left(\mathrm{h}_{7}-\mathrm{h}_{6}\right)$

$\mathrm{m}_{\mathrm{w}}\left(\mathrm{h}_{8}-\mathrm{h}_{9}\right)=\left(\mathrm{m}_{\mathrm{w}}+1\right)\left(\mathrm{h}_{7}-\mathrm{h}_{6}\right)$

$\mathrm{m}_{\mathrm{w}}(535-220)=\left(\mathrm{m}_{\mathrm{w}}+1\right)(340-75)$

$\mathrm{m}_{\mathrm{w}}=5.3 \mathrm{~kg} / \mathrm{kg}$ of $\mathrm{NH}_{3}$

Mass of solution handled by pump

$$
\begin{aligned}
& =\mathrm{m}_{\mathrm{r}} \times\left(\mathrm{m}_{\mathrm{w}}+1\right) \\
& =0.005 \times(5.3+1)
\end{aligned}
$$

$\mathrm{m}_{\mathrm{r}}=0.003123 \mathrm{~kg} / \mathrm{sec}$

Actual C.O.P. $=\mathrm{Q}_{\mathrm{r}} / \mathrm{Q}_{\mathrm{g}}$

$=1.5 \times 3.52 / 10.51$

$=0.562$

Percentage $\eta$ of the system

$=34.83 \%$

Total heat rejected in various components $=0.0044 \times 1350=6$ watts

Percentage $\eta$ of generator $=80 \%$

1. Heat supplied to generator

$$
\mathrm{Q}_{\mathrm{g}}=6+6(1-1.8)
$$

$=7.2$ watts

2. Heat supplied from absorber

$\mathrm{Q}_{\mathrm{a}}=1565 \times 0.0044$

$=6.88$ watts

3. Heat rejected in condenser

$\mathrm{Q}_{\mathrm{c}}=1080 \times 0.0044$

$=4.75$ watts

$\mathrm{m}_{\mathrm{r}}$ : rate of mass transfer from evaporator to absorber Hence

$\mathrm{m}_{\mathrm{r}}=\mathrm{m}_{\mathrm{a}}+\mathrm{m}_{\mathrm{c}}$

$=0.0044 \mathrm{gm} / \mathrm{sec}$ 


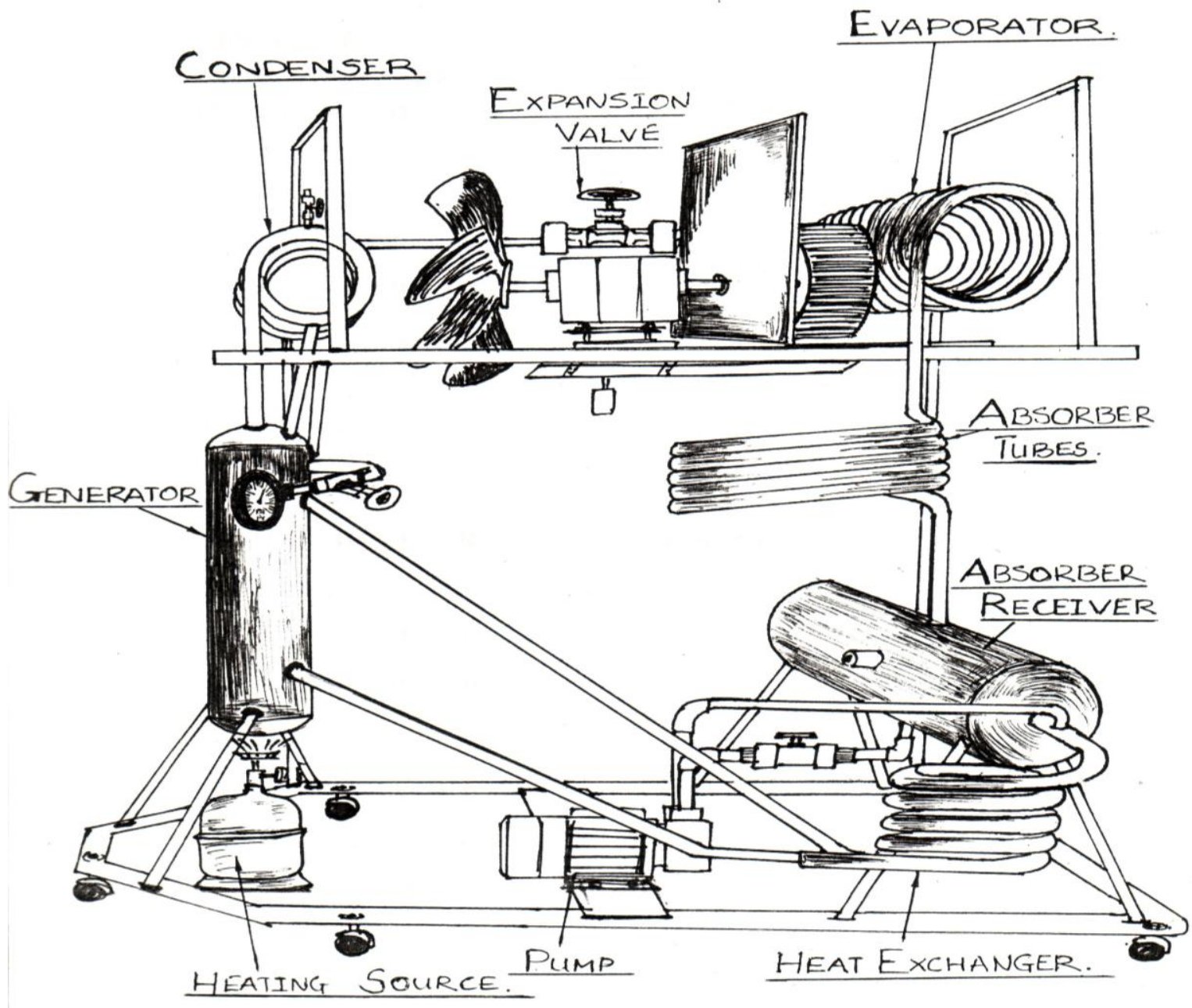

Fig.1:- Experimental set up. 


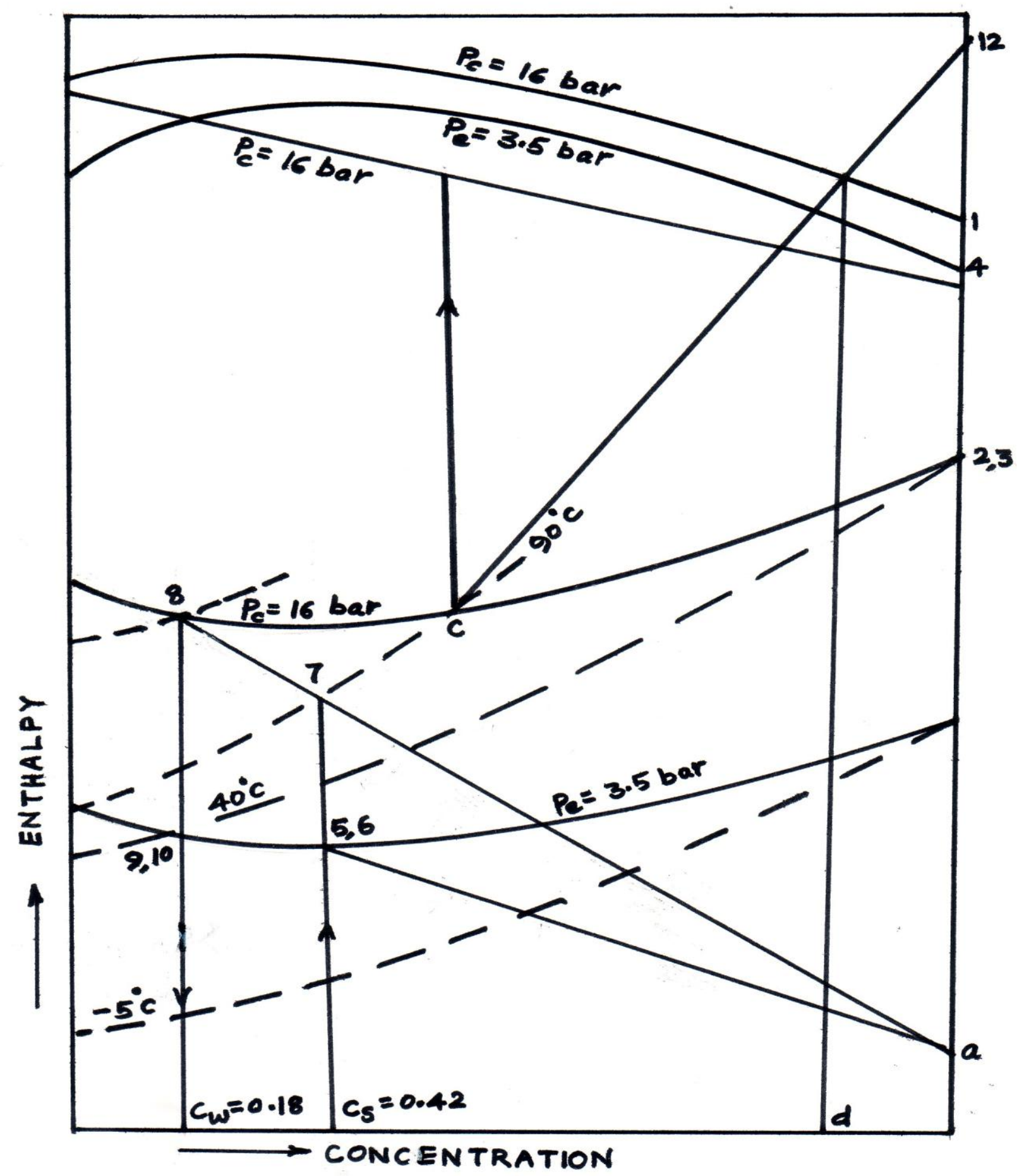

Fig. 2:- Enthalpy-Concentration Diagram 


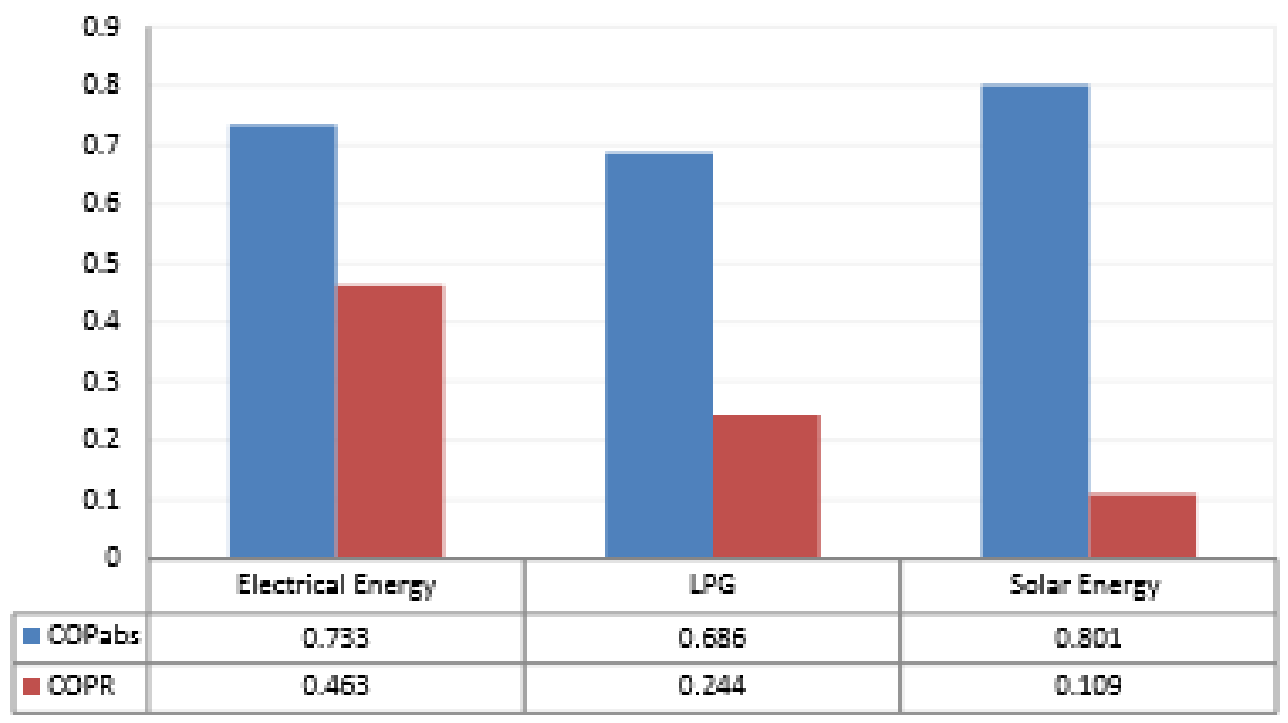

Fig 3:- The C.O.P. for many types of energy runs the absorption refrigeration system.

\section{Discussion:-}

The absorption refrigeration system was used to test and compare the suitability of different sources of energy and their impact on working conditions at the absorption refrigeration process Sameh Alsaqoor et.al[9].According to them it has been observed experimentally that theoretical C.O.P. which is calculated only on the basis of the measured temperature at various points in the system, as temperature on the generator, temperature on the absorber, temperature on the evaporator and temperature on the condenser almost all equal and varies between 0.69 to 0.8(shown in Fig.3) for all three kinds of sources of energy (Electrical energy, LPG gas and solar energy with the help of flat plate solar collector). In the present experimental study, theoretical C.O.P. and actual C.O.P. for LPG gas comes as 0.78 and 0.562 respectively which could well match with the range of theoretical C.O.P. [9]

\section{Conclusion:-}

Large capacity air conditioning equipment powered by gas (CNG or LPG) helps to overcome the cost and problems associated with the growth in demand for air conditioning will increase as gas and electricity supplies are deregulated. The setting up of a field trial could still be an effective option giving time to study the market requirements and establishing a working relationship with a gas utility and hence it is concluded that this type of system is an important aspect of the development of market for gas fired air-conditioning.

\section{References:-}

1. Hattem, D.V. and Dato, P.A. (1981) Description of an Active Solar Cooling System, Using a LiBr-H2O Absorption.

2. Chinnappa, J.C., Crees, M.R., Murthy, S.S. and Srinivasan, K. (1993) Solar-Assisted Vapor Compression/Absorption Cascaded Air-Conditioning Systems. Solar Energy, 50, 453-458. http://dx.doi.org/10.1016/0038-092X(93)90068-Y.

3. Best, R. and Ortega, N. (1999) Solar Refrigeration and Cooling. Renewable Energy, 16, 685-690. http://dx.doi.org/10.1016/S0960-1481 (98)00252-3 [7] Chen, G.M. and Hihara, E. (1999) Anew Absorption Refrigeration Cycle Using Solar Energy. Solar Energy, 66, 479- 482. http://dx.doi.org/10.1016/S0038092X(99)00042-0.

4. Deng, S.M. and Ma, W.B. (1999) Experimental Studies on the Characteristics of an Absorber Using LiBr/H2O Solution as Working Fluid. International Journal of Refrigeration, 22, 293-301. http://dx.doi.org/10.1016/S0140-7007 (98)00067-X.

5. Rivera, W. and Xicale, A. (2001) Heat Transfer Coefficients in Two Phase Flow for the Water/Lithium Bromide Mixture Used in Solar Absorption Refrigeration Systems. Solar Energy Materials and Solar Cells, 70, 309-320. 
6. Grossman, G. (2002) Solar Powered Systems for Cooling, Dehumidification, and Air Conditioning. Solar Energy,72,53-62. http://dx.doi.org/10.1016/S0038-092 X (01)00090-1.

7. Lokurlu, A. and Müller, G. (2005) Experiences with the World Wide First Solar Cooling System Based on Trough Collectors Combined with Double Effect Absorption Chillers. Proceedings of the International Conference on Solar Air-Conditioning, Bad Staffelstein.

8. AlQdah, K.S. (2011) Performance and Evaluation of Aqua Ammonia Auto Air Conditioner System Using Exhaust Waste Energy. Energy Procedia, 6, 467-476. http://dx.doi.org/10.1016/j.egypro.2011.05.054.

9. Sameh Alsaqoor1, Khaled S. AlQdah(2014) Performance of a Refrigeration Absorption Cycle Driven by Different Power Sources-Smart Grid and Renewable Energy, 5, 161-169 Published Online July 2014 in SciRes. http://www.scirp.org/journal/sgre http://dx.doi.org/10.4236/sgre.2014.57015. 